\title{
Renal proteinases and kidney hypertrophy in experimental diabetes
}

\author{
L. Schaefer, R. M. Schaefer, H. Ling, M. Teschner, A. Heidland \\ Department of Nephrology, University of Wuerzburg, Germany
}

Summary IDDM is associated with an increase in kidney size, which is due to cellular hypertrophy and progressive matrix accumulation within the glomerulus and throughout the tubulointerstitium. The present study addressed the potential role of cysteine and metalloproteinases in renal hypertrophy of short-term diabetes. Three weeks after induction of streptozotocin diabetes in rats, intraglomerular gelatinase activity (streptozotocin: $23 \pm 4$ vs control: $44 \pm 3 \mathrm{mU} / \mu \mathrm{g}$ DNA) and cathepsin L $+\mathrm{B}$ activity (streptozotocin: $6.7 \pm 0.8$ vs control: $9.3 \pm 0.7 \mathrm{U} / \mu \mathrm{g}$ DNA) were significantly decreased. Insulin treatment completely prevented the decline in glomerular proteinase activity (gelatinase: $37 \pm 6 \mathrm{mU} / \mu \mathrm{g}$ DNA; cathepsin L + B: $9.6 \pm 0.9 \mathrm{U} / \mu \mathrm{g}$ DNA). In isolated proximal tubules a similar pattern of enzyme activity could be observed. Three weeks of diabetes caused a significant decline in cathepsin L $+B$ activity (streptozotocin: $28 \pm 2$ vs control: $37 \pm 3 \mathrm{U} / \mu \mathrm{g}$ DNA). Insulin treatment again prevented the decline in these tubular proteinase activities. In parallel, kidney weight increased by $22 \%$ and glomerular protein/DNA ratio rose by $17 \%$ in untreated diabetic rats. Diabetic rats receiving insulin displayed a normal glomerular protein/DNA ratio and the kidney weight was increased by only $5 \%$. These results show that renal hypertrophy of early diabetes is closely associated with a decline in both glomerular and tubular proteinase activity. Adequate insulin substitution prevented renal hypertrophy and the reduction in proteinase activity. [Diabetologia (1994) 37: 567-571]

Key words IDDM, streptozotocin, tubules, glomeruli, collagenase, gelatinase, cathepsins, hypertrophy.
Both in man and animals diabetes mellitus is associated with an early increase in kidney size [1-3], which is based on cellular hypertrophy [4] and enhanced extracellular matrix accumulation within the glomerulus and throughout the tubulointerstitium [5]. In general, intra- or extracellular protein accretion may be caused

Received: 24 September 1994

and in revised form: 10 January 1994

Corresponding author: Dr. L. Schaefer, Department of Nephrology, Medizinische Universitätsklinik, Josef-Schneider-Str.2, D-97080 Würzburg, Germany

Abbreviations: AMC, 7-Amino-4-methyl coumarin; EDTA, ethylene diamine tetra-acetic acid; PMSF, phenylmethylsulfonyl fluoride; TGF- $\beta$, transforming growth factor- $\beta$; TIMP, tissue inhibitor of metalloproteinases; GFR, glomerular filtration rate; IDDM, insulin-dependent diabetes mellitus either by enhanced synthesis or reduced breakdown or both. Recently, Prigent-Sassy and co-workers [6] analysed the $\alpha 1$ (IV) and $\alpha 2$ (IV) collagen mRNAs extracted from the renal cortex of diabetic rats and found no increase in collagen synthesis between 1 week and 6 months of diabetes despite considerable glomerulosclerosis. Based on these findings the authors concluded that the deposition of extracellular matrix under these circumstances is not related to increased collagen synthesis, but is more likely due to a defect in matrix protein catabolism.

This notion is consistent with earlier observations in diabetic animals where reduced renal proteolytic activity $[7,8]$ and lower activities of lysosomal enzymes such as cathepsins L and B [9, 10] and cathepsin D [11] have been reported. Reduced proteinase activity in turn may lead to hypertrophy and matrix accumulation, as it has been demonstrated that inhibition of lysosomal pro- 
teinases does suppress intracellular protein breakdown by up to $70 \%$ [12].

In the present investigation two classes of renal proteinases, namely neutral metalloproteinases (gelatinase and collagenase) and cysteine proteinases (cathepsins $\mathrm{L}+\mathrm{B}$ and $\mathrm{H}$ ), were studied in a short-term model of diabetes. Gelatinase and collagenase are metalloproteinases which are capable of degrading collagens and other matrix components. In vivo these enzymes are secreted extracellularly and are supposed to play an important role in matrix turnover [13]. The cathepsins are cysteine proteinases with an acidic $\mathrm{pH}$ optimum, which are located within lysosomes and are believed to be involved in intra- and extracellular protein degradation [14].

The aim of this study was to relate the activities of renal proteinases with the evolution of kidney hypertrophy in streptozotocin-induced diabetes of the rat.

\section{Materials and methods}

\section{Animals}

Male Wistar rats (Ivanovas, Kisslegg, Germany), weighing 200$250 \mathrm{~g}$, were used for all experiments. Groups of two animals were housed in single cages in a room at constant humidity and temperature with a controlled 12-h light dark cycle. For measurements of proteinuria animals were kept in metabolic cages for $24 \mathrm{~h}$. The animals had free access to tap water and standard rat chow (Altromin, Lippe/Westphalia, Germany) throughout the study. After a 5-day adaptation period, diabetes was induced by intravenous administration of streptozotocin in a dose of $60 \mathrm{mg} / \mathrm{kg}$ body weight. The diabetic animals were divided into three groups of 10 animals each. Group 1 comprised diabetic animals which were on insulin therapy. The target serum glucose was $8.5-14.0 \mathrm{mmol} / \mathrm{l}$. Group 2 comprised diabetic animals with no insulin treatment, with a target serum glucose of more than $19.5 \mathrm{mmol} / 1$. Group 3 were the non-diabetic animals.

Insulin (UItralente, Novo, Copenhagen, Denmark) was given subcutaneously once per day. The dose was individually adjusted according to biweekly determined blood glucose concentrations (2.5-5 IU/24 h). By contrast, rats in group 2 (no insulin treatment) received only a small daily dose of insulin (0.3 IU/24 h) to prevent ketoacidosis.

\section{Isolation of tubules and glomeruli}

Three weeks after induction of diabetes, animals were anaesthetized with hexobarbital $(150 \mathrm{mg} / \mathrm{kg})$ and the kidneys were harvested. The organs were dissected longitudinally, the medulla was excised and the remaining cortical tissue was minced. This homogenate was passed through stainless steel sieves with pore sizes of $250 \mu \mathrm{m}$ (Linker, Kassel, Germany). The sieved material was suspended in ice-cold $0.9 \% \mathrm{NaCl}$ and poured on a $50-\mu \mathrm{m}$ nylon sieve (Schweizerische Seidengazefabrik, Zurich, Switzerland), thereby allowing cell debris and small fragments to pass through, while glomeruli and tubules were retained. Separation of glomeruli from tubules was achieved by using a $150-\mu \mathrm{m}$ nylon sieve which retains tubules and allows glomeruli to pass through. Both glomeruli and tubules were suspended in $0.9 \% \mathrm{NaCl}$, gently centrifuged at $400 \times g$ and examined by light microscopy. The purity of both preparations was between $90-95 \%$.

\section{Analytical methods}

Isolated glomeruli $(3 \times 2 \mathrm{~s})$ and tubules $(5 \times 2 \mathrm{~s})$ were disrupted by sonication at $4^{\circ} \mathrm{C}$. The activities of cathepsins $\mathrm{L}+\mathrm{B}$ and $\mathrm{H}$ were assayed as previously described by Barrett [15] and Barrett and Kirschke [16] using fluorogenic peptidyl substrates (Bachem, Heidelberg, Germany): H-Arg-AMC for cathep$\sin \mathrm{H}$, and Z-Phe-Arg-AMC for cathepsin B $+\mathrm{L}$. In the case of cathepsin $\mathrm{H}, 0.1 \mathrm{mmol} / \mathrm{l}$ puromycin was used to inhibit non-specific degradation of $\mathrm{H}$-Arg-AMC by aryl-amidases. The fluorescence of free AMC was determined by excitation at $380 \mathrm{~nm}$ and emission at $460 \mathrm{~nm}$. All activity was expressed per $\mu \mathrm{g}$ DNA.

The activities of collagenase and gelatinase were measured fluorometrically according to Tschesche et al. [17] using native or denatured rat tail collagen type-1 in the presence or absence of EDTA $(20 \mathrm{mmol} / \mathrm{l})$. Latent enzyme activity was detected by preincubating samples with $0.5 \mathrm{mmol} / \mathrm{l}$ of oxidized glutathione. To examine the purity of native collagen, digestion with trypsin was measured. Collagenase measurements were carried out at $25^{\circ} \mathrm{C}$ to prevent denaturation of collagen. The activity of gelatinase was determined in the presence of $4 \mathrm{mmol} / \mathrm{PMSF}$ for inhibition of serine proteinases. After $18 \mathrm{~h}$ of incubation, the digested collagen fragments were labelled with $2 \%$ fluorescamine. Fluorescence was measured by excitation at $390 \mathrm{~nm}$ and emission at $460 \mathrm{~nm}$ and was quantitated using a Luminescence Spectrometer LS 50 from Perkin Elmer (Langen, Germany).

SDS substrate gels were prepared by including gelatin at a final concentration of $1 \mathrm{mg} / \mathrm{ml}$ in the standard $7.5 \%$ Laemmli acrylamide polymerization mixture. The samples were solubilized in non-reducing sample buffer and electrophoresed at $4^{\circ} \mathrm{C}$ and $100 \mathrm{~V}$. After electrophoresis gels were washed for 30 min at room temperature in $2.5 \%$ Triton X-100 and then incubated at $37^{\circ} \mathrm{C}$ over-night in $50 \mathrm{mmol} / \mathrm{l}$ Tris- $\mathrm{HCl}, 0.1 \mathrm{~mol} / \mathrm{l} \mathrm{NaCl}$, $10 \mathrm{mmol} / 1 \mathrm{CaCl}_{2}, 0.05 \% \mathrm{Brij} \mathrm{pH} 7.6$ in the presence and absence of $20 \mathrm{mmol} / 1 \mathrm{EDTA}$. Gels were stained with coomassie blue R250 and destained in $40 \%$ methanol/10\% acetic acid. As a standard a high-molecular mass standard mixture $(205 \mathrm{kDa}-$ $29 \mathrm{kDa}$ Laemmli) from Sigma (Munich, Germany) was used.

Tissue DNA content was determined according to the method of Labarca and Peigen [18]. Briefly, DNA in tissue homogenates was labelled with Bisbenzimide (H 33258, Riedel-deHaen, Seelze, Germany) which enhances the natural fluorescence of DNA several fold. The excitation wavelength was $355 \mathrm{~nm}$ and emission was measured at $460 \mathrm{~nm}$.

Analysis of serum and urine samples for glucose, electrolytes, urea-nitrogen, and creatinine was performed using a Technicon autoanalyser (Bayer Diagnostics, Munich, Germany). Urinary albumin was measured by nephelometry using a rabbit antibody against rat albumin obtained from Organon Technika (Eppelheim, Germany).

Protein content in tissue homogenates was measured according to the method of Smith et al. [19]. Proteins in tissue homogenates were labelled with bicinochonicinic acid (Pierce, Beijerland, The Netherlands) and incubated for $30 \mathrm{~min}$ at $60^{\circ} \mathrm{C}$. The optical density was measured at $562 \mathrm{~nm}$. Bovine serum albumin was used as standard in a range from $5-500 \mu \mathrm{g} / \mathrm{ml}$.

\section{Statistical analysis}

Results were expressed as means \pm SEM from 9-10 animals in each group. Statistical analysis was performed using the unpaired Student's $t$-test. Significance was accepted at the $5 \%$ level. 
Table 1. Effect of insulin treatment in diabetic rats on single kidney weights and glomerular protein/DNA ratios

\begin{tabular}{|c|c|c|}
\hline & \multicolumn{2}{|c|}{ Non-diabetic Diabetic rats } \\
\hline & control rats. & untreated insulin-treated \\
\hline Kidney weight (mg) & $995 \pm 10$ & $1210 \pm 25^{\mathrm{a}, \mathrm{b}} 1040 \pm 10^{\mathrm{a}}$ \\
\hline $\begin{array}{l}\text { Kidney weight/ } \\
\text { body weight } \times 10^{3}\end{array}$ & $3.5 \pm 0.3$ & $5.5 \pm 0.6^{\mathrm{a}, \mathrm{b}}$ \\
\hline $\begin{array}{l}\text { Glomerular } \\
\text { protein/DNA }\end{array}$ & $14.6 \pm 0.8$ & $17.5 \pm 0.6^{\mathrm{a}, \mathrm{b}} \quad 15.0 \pm 0.8$ \\
\hline
\end{tabular}

Results are given as means \pm SEM from 9-10 animals.

${ }^{a} p<0.05$ for diabetic rats vs healthy controls;

${ }^{\mathrm{b}} p<0.05$ for untreated diabetic rats vs insulin-treated diabetic rats

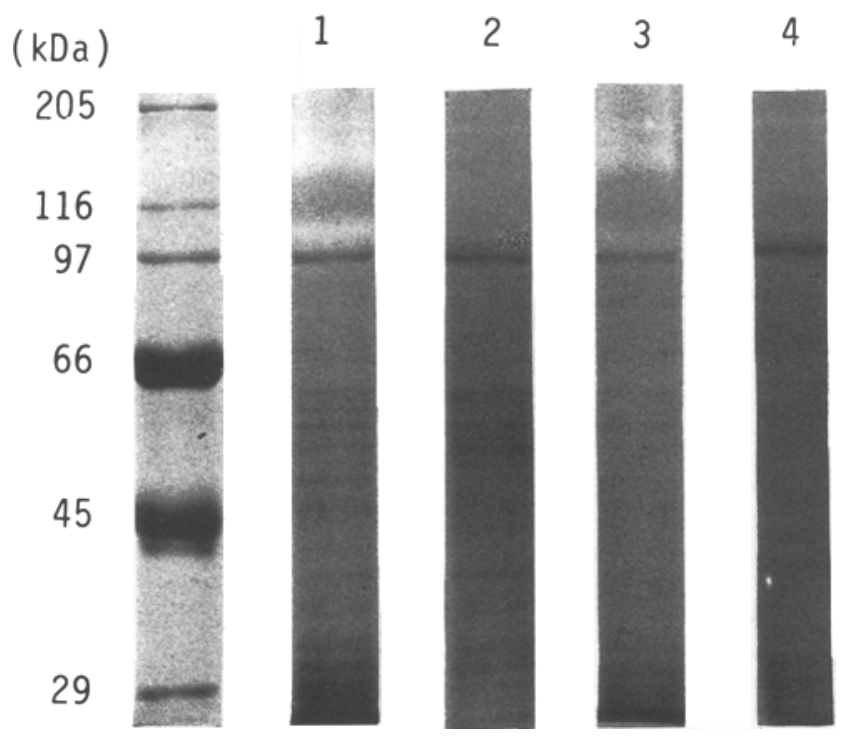

Fig. 1. Zymogram of glomerular gelatinases (95 and $120 \mathrm{kDa}$ forms) from healthy and diabetic rats both in the presence and absence of $20 \mathrm{mmol} / 1 \mathrm{EDTA}$. Lane 1, non-diabetic rats; lane 2, non-diabetic rats + EDTA; lane 3, diabetic rats, lane 4, diabetic rats + EDTA

\section{Results}

\section{Manifestation of diabetes mellitus}

Three days after the injection of streptozotocin, the rats developed significant hyperglycaemia $(18.1 \pm 0.4$ vs $5.1 \pm 0.1 \mathrm{mmol} / \mathrm{l}$ ) compared with control animals. Throughout the 3-week experimental period untreated diabetic rats displayed 4-6 times higher serum glucose levels compared to non-diabetic controls. Near normoglycaemia was achieved in diabetic rats receiving insulin. Polyuria developed early in the course of diabetes and overnight urine volume was $65 \pm 11 \mathrm{ml} / 24 \mathrm{~h}$ in untreated and $27 \pm 7 \mathrm{ml} / 24 \mathrm{~h}$ in treated diabetic animals. By contrast, non-diabetic controls had mean urinary volumes of $18 \pm 2 \mathrm{ml} / 24 \mathrm{~h}$. Albuminuria was significantly enhanced in diabetic animals (untreated: $810 \pm 150 \mu \mathrm{g} / 24 \mathrm{~h}$, treated: $671 \pm 100 \mu \mathrm{g} / 24 \mathrm{~h}) \mathrm{com}-$ pared to normal rats $(340 \pm 40 \mu \mathrm{g} / 24 \mathrm{~h})$.

\section{Renal hypertrophy}

Three weeks after induction of diabetes kidney weights in untreated diabetic rats were significantly higher $(+22 \%)$ than in non-diabetic animals. Insulin-treated diabetic animals had considerably attenuated renal hypertrophy (kidney weight gain: $+5 \%, p<0.05$ ). In addition, protein/DNA ratios of isolated glomeruli were used as a parameter of glomerular hypertrophy. Compared to non-diabetic controls untreated diabetic rats displayed higher ratios $(+20 \%, p<0.05)$ suggesting glomerular hypertrophy, whereas insulin treatment kept this ratio within the range of control animals (Table 1).

\section{Glomerular proteinases}

Collagenase and gelatinase activities were measured in freshly isolated glomeruli. Collagense activity was not statistically different between diabetic and nondiabetic animals. On the other hand, gelatinase activities were significantly lower in untreated diabetic rats. Compared to healthy animals $(43.5 \pm 3.3 \mathrm{mU} / \mu \mathrm{g}$ DNA) untreated diabetic animals had markedly lower gelatinase activity $(23.1 \pm 3.5 \mathrm{mU} / \mu \mathrm{g}$ DNA, $p<0.05)$, whereas insulin treatment partially prevented the decline in enzyme activity $(36.6 \pm 6.4 \mathrm{mU} / \mu \mathrm{g}$ DNA, $p<$ 0.05 ).

Using zymography, a $95 \mathrm{kDa}$ and a $120 \mathrm{kDa}$ gelatinase could be identified in glomeruli of both healthy and diabetic animals. In agreement with the fluorometric analysis, diabetic rats displayed lower gelatinase activity as compared with healthy controls (Fig. 1, lane 3 vs 1). Semi-quantitative measurement of the enzyme activity was achieved by adjusting each sample to the same DNA concentration. The metalloproteinase character of this enzyme activity was proven by inhibition with EDTA (Fig. 1, lane 2 and 4).

A similar pattern was observed with glomerular cysteine proteinases. There was a significant fall in enzyme activity in untreated diabetes compared to healthy controls (cathepsin $\mathrm{L}+\mathrm{B}$ : $6.7 \pm 0.8$ vs $9.3 \pm 0.7 \mathrm{U} / \mu \mathrm{g}$; cathepsin H: $1.3 \pm 0.2$ vs $1.9 \pm 0.2 \mathrm{U} / \mu \mathrm{g}$ DNA, $p<0.05$ ). Insulin treatment completely prevented the decline in cathepsin activity (cathepsin L + B: $9.6 \pm 0.9 \mathrm{U} / \mu \mathrm{g}$; cathepsin $\mathrm{H}: 1.7 \pm 0.2 \mathrm{U} / \mu \mathrm{g}$ DNA, $p<0.05)$.

\section{Tubular cysteine proteinases}

The activities of cathepsins $\mathrm{L}+\mathrm{B}$ and $\mathrm{H}$ were measured in isolated proximal tubules. Compared to non-diabetic rats, there was a profound decrease in cathepsin activity (cathepsin $\mathrm{L}+\mathrm{B}: 37.0 \pm 2.6$ vs $28.2 \pm$ $1.7 \mathrm{U} / \mu \mathrm{g}, \quad p<0.05$; cathepsin $\mathrm{H}: 8.1 \pm 0.5$ vs $6.7 \pm$ $0.3 \mathrm{U} / \mu \mathrm{g}$ DNA, $p<0.05)$ in untreated diabetic animals. This decline in enzyme activity could be complete- 
ly prevented by insulin treatment (cathepsin $\mathrm{L}+\mathrm{B}$ : $36.4 \pm 2.4 \mathrm{U} / \mu \mathrm{g}, p<0.05$; cathepsin $\mathrm{H}: 7.6 \pm 0.4 \mathrm{U} / \mu \mathrm{g}$ DNA, $p<0.05)$.

\section{Discussion}

In the present study, 3 weeks of streptozotocin-induced diabetes in the rat caused a significant decline in the activities of lysosomal cathepsins and neutral metalloproteinases both in the glomeruli as well as the proximal tubules, which was accompanied by a $22 \%$ increase in kidney weight. These observations are in good agreement with earlier reports that GFR and kidney weight are increased in the streptozotocindiabetic rat in poor metabolic control but without ketonuria [20]. These renal alterations are similar with those observed in human IDDM [1,2]. For these reasons, Jensen et al. [21] have suggested that the streptozotocin-diabetic rat may be considered a useful experimental model for studying the early renal alterations in human IDDM.

There are three major concerns about measuring renal proteinases in this specific animal model:

1. does streptozotocin itself exert any effects on renal proteinases? Our observations indicate that insulin prevented the fall in proteinase activity, thus it is unlikely that streptozotocin influenced proteinase activity in this model.

2. Normally enzyme activity in tissues are expressed as activity per mg protein content. However, this cannot be done in the presence of tissue hypertrophy, as protein content is no longer constant, but increasing. For these reasons, we related all proteinase activity to $\mu \mathrm{g}$ DNA, since only minimal cell proliferation in the glomerulus or the tubulointerstitium occurs in the kidney 6 weeks after streptozotocin administration [22].

3. It also could be argued that proteinuria may have influenced the enzyme activity in this short-term model of diabetes. However, in a study by Olbricht et al. [23] proteinuria stimulated tubular proteinases. Therefore, it seems unlikely that reduced activity in this model was due to enhanced urinary protein excretion.

The crucial question of this study is whether reduced renal proteinase activities indeed reflect decreased intra- and extracellular protein degradation. While we do not have direct experimental evidence, several observations suggest a close relationship. Inhibition of lysosomal cathepsins may reduce intracellular protein breakdown by up to $70 \%$ [24-26], whereas protein degradation has been shown to be paralleled by enhanced cathepsin activity [27-30]. These findings support the view that lysosomal proteinases are related to intracellular protein turnover, such that reduced activity would favour protein accumulation. It is also conceivable that a similar relation exists for extracellular matrix turnover, where enhanced matrix deposition could be facilitated by reduced activity of metalloproteinases.

Finally, accumulating evidence implicates TGF- $\beta$ as a cytokine relevant in enhanced renal matrix deposition in diabetes [31]. In general, TGF- $\beta$ stimulates the synthesis of various matrix components, such as fibronectin, collagens, and proteoglycans [32-34]. It simultaneously attenuates matrix degradation by reducing the synthesis of serine, cysteine-, and metalloproteinases [35] and by increasing the levels of their specific inhibitors, such as cystatin C and TIMP $[35,36]$.

In diabetes, Border and Ruoslahti [31] showed that TGF- $\beta$ mRNA increased with time in glomeruli from streptozotocin-diabetic rats and that this increment could be reduced by insulin treatment. Immunohistochemically TGF- $\beta$ protein has been demonstrated to be increased in the diabetic kidney. These findings are consistent with our observations of reduced renal cysteine- and metalloproteinase activities in kidneys from diabetic rats, suggesting that this decline in renal proteinase activity may be mediated by enhanced tissue concentrations of TGF- $\beta$.

Our findings reported here provide additional evidence that renal hypertrophy in diabetic rats is associated with a significant decline in the activities of renal cysteine and metalloproteinases. Further support is provided by the fact that adequate insulin treatment almost completely prevented renal hypertrophy as well as the decline in glomerular and tubular proteinase activities.

Acknowledgements. This work was supported by the Deutsche Forschungsgemeinschaft, grant 149/11. The technical help of Ms. I. Baldauf, Ms. M. Scheurich and Ms. M. Schott is gratefully acknowledged.

\section{References}

1. Mogensen CE, Anderson MJF (1973) Increased kidney size and glomerular filtration rate in early juvenile diabetes. Diabetes 22: 706-712

2. Mogensen CE, Andersen MJF (1975) Increased kidney size and glomerular filtration rate in untreated juvenile diabetics: normalization by insulin treatment. Diabetologia 11: 221 224

3. Seyer-Hansen K (1976) Renal hypertrophy in streptozotocin-diabetic rats. Clin Sci Mol Med 51: 551-555

4. Seyer-Hansen K, Hansen J, Gunderson HJG (1980) Renal hypertrophy in experimental diabetes. A morphometric study. Diabetologia 18: 501-505

5. Osterby R, Gunderson HJG, Götzsche O, Seyer-Hansen K (1980) The rate of synthesis and breakdown of glomerular basement membrane material at the transition of "normal to diabetes' and 'diabetes to normal'. Renal Physiol 3: 298-303

6. Prigent-Sassy C, Bruneval P, Heudes D, Belair MF, Bariety J (1993) Glomerulosclerosis in streptozotocin-induced diabetic rats: absence of increased synthesis of type IV collagen. XXXth Congress EDTA, Glasgow, p 18 (Abstract)

7. Teschner M, Schaefer RM, Svarnas A, Heidland U, Heidland A (1989) Decreased proteinase activity in isolated 
glomeruli of streptozotocin diabetic rats. Am J Nephrol 9: 464-469

8. Lubec G, Leban J, Peyroux J et al. (1982) Reduced collagenolytic activity of rat kidneys with streptozotocin diabetes. Nephron 30: 357-360

9. Shechter P, Bonner G, Rabkin R (1991) Depressed protein breakdown and cathepsin activity contribute to renal hypertrophy. JASN 2: 297 (Abstract)

10. Olbricht CJ, Geissinger B (1992) Renal hypertrophy in streptozotocin diabetic rats: role of proteolytic enzymes. Kidney Int 41: 966-972

11. Nerurkar MA, Satav JG, Katyare SS (1988) Insulin-dependent changes in lysosomal cathepsin $\mathrm{D}$ activity in rat liver, kidney, brain and heart. Diabetologia 31: 119-122

12. Kairallah EA (1985) Quantitative assessment of the contribution of autophagy to intracellular protein breakdown. Biochem Soc Trans 13: 1012-1015

13. Davies M, Thomas GJ, Martin J, Lovett DH (1988) The purification and characterization of a glomerular-basementmembrane-degrading neutral proteinase from rat mesangial cells. Biochem J 251: 419-425

14. Thomas GJ, Davies M (1989) The potential role of human kidney cortex cysteine proteinases in glomerular basement membrane degradation. Biochem Biophys Acta 990: 246253

15. Barrett AJ (1980) Fluorometric assay for cathepsin B and cathepsin $\mathrm{H}$ with methylcoumarylamide substrates. Biochem $\mathrm{J}$ 187:909-912

16. Barrett AJ, Kirschke H (1981) Cathepsin B, cathepsin H and cathepsin L. Meth Enzymol 80: 535-561

17. Tschesche H, McCartney HW, Fedrowitz J (1981) Gelatinase and collagenase. In: Bergmeyer HU (ed) Methods of enzymatic analysis, pp 155-159 and 239-248

18. Labarca C, Peigen K (1979) A simple, rapid, and sensitive DNA assay procedure. Anal Biochem 102: 344-352

19. Smith PK, Krohn RJ, Hermanson GT et al. (1985) Measurement of protein using Bicinochoninic acid. Anal Biochem 150: $76-85$

20. Hostetter TH, Troy JL, Brenner BM (1981) Glomerular hemodynamics in experimental diabetes mellitus. Kidney Int 19: 410-415

21. Jensen PK, Sandahl Christiansen J, Steven K, Parving HH (1981) Renal function in streptozotocin-diabetic rats. Diabetologia 21: 409-414

22. Young B, Johnson R, Alpers C, Eng E, Floege J, Couser W (1993) Several early cellular events in glomeruli precede the development of glomerulosclerosis in experimental diabetic nephropathy. XIIth Int Congress Nephrol, Jerusalem 1993, pp 422 (Abstract)
23. Olbricht CJ, Cannon JK, Garc LC, Tisher CC (1986) Activities of cathepsin B and $L$ in isolated nephron segments from proteinuric and nonproteinuric rats. Am J Physiol 250: F1055-F1062

24. Seglen PO, Gordon PB, Tolleshaug H (1985) Autophagy and protein degradation in isolated hepatocytes. Biochem Soc Trans 13: 1007-1010

25. Libby P, Goldberg AL (1978) Leupeptin, a protease inhibitor, decreased protein degradation in normal and diseased muscles. Science 199: 534-536

26. Neff NT, DeMartino GN, Goldberg AL (1979) The effect of protease inhibitors and decreased temperature on the degradation of different classes of proteins in cultured hepatocytes. J Cell Physiol 101: 439-458

27. DeMartino GN, Goldberg AL (1978) Thyroid hormones control lysosomal enzyme activities in liver and muscle. Proc Natl Acad Sci USA 196: 1369-1373

28. Tolnai S, Korecky B (1980) Lysosomal hydrolases in the heterotopically isotransplanted heart undergoing atrophy. $\mathrm{J}$ Mol Cell Cardiol 12: 869-890

29. Kominami E, Tsukahara T, Bando Y, Katunuma N (1985) Distributions of cathepsins $B$ and $H$ in rat tissues and peripheral blood cells. J Biochem 98: 87-93

30. Ruff RL, Secrist D (1984) Inhibitors of prostaglandin synthesis or cathepsin B prevent muscle wasting due to sepsis in the rat. J Clin Invest 73: 1483-1486

31. Border WA, Ruoslahti E (1992) Transforming growth factor$\beta$ in disease: the dark side of tissue repair. J Clin Invest 90: 1-7

32. Ignotz RA, Massague J (1986) Transforming growth factor beta stimulates the expression of fibronectin and collagen and their incorporation into the extracellular matrix. J Biol Chem 261: 4337-4345

33. Bassols A, Massague J (1988) Transforming growth factor $\beta$ regulates the expression and structure of extracellular matrix chondroitin/dermatan sulfate proteoglycans. J Biol Chem 263: 3039-3045

34. Solem M, Rawson C, Linburg K, Barnes D (1990) Transforming growth factor beta regulates cystatin $\mathrm{C}$ in serumfree mouse embryo cells. Biochem Biophys Res Commun 172: $945-951$

35. Edwards DR, Murphy G, Reynolds JJ et al. (1987) Transforming growth factor beta modulates the expression of collagenase and metalloproteinase inhibitor. EMBO J 6: 18991904

36. Laiho M, Saksela O, Keski-Oja J (1987) Transforming growth factor- $\beta$ induction of type- 1 plasminogen activator inhibitor. J Biol Chem 262: 17467-17474 